\title{
A Rare Case; Hydatid Cyst of the Breast
}

\author{
Nadir Bir Olgu; Memenin Kist Hidatik Hastahğ

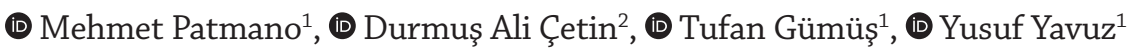 \\ ${ }^{1}$ Şanliurfa Training and Research Hospital, Clinic of General Surgery, Şanliurfa, Türkiye \\ ${ }^{2}$ Şanlıurfa Training and Research Hospital, Clinic of Gastroenterological Surgery, Şanlıurfa, Türkiye
}

Cite this article as: Patmano M, Çetin DA, Gümüş T, Yavuz Y. A Rare Case; Hydatid Cyst of the Breast. Turkiye Parazitol Derg 2019;43(1):47-9.

\begin{abstract}
Hydatid cyst is a helminthic infection caused by Echinococcus granulosus that we encounter in various organs, especially in the liver and the lungs. Hydatid cyst of the breast is seen very rarely even in regions where the disease is endemic. In this article, we aimed to present a female patient who presented with complaints of a mass in her right breast, was diagnosed as having hydatid cyst as a result of physical examination and radiological imaging methods, and was treated.
\end{abstract}

Keywords: Hydatid cyst, mass in the breast, hydatid cyst of the breast

ÖZ

Kist hidatik hastalığı başta karaciğer ve akciğer olmak üzere birçok organda kistlerle karşımıza çıkan, Echinococcus granulosus kaynaklı helmintik bir enfeksiyondur. Meme kist hidatiği hastalı̆̆ın endemik olduğu bölgelerde dahi oldukça nadir görülür. Biz bu yazıda sağ memede ele gelen sertlik nedeniyle başvuran, fizik muayene ve radyolojik görüntüleme yöntemleri sonucu meme kist hidatiği tespit edilen ve tedavi edilen bir hastayı sunmayı amaçladık.

Anahtar Kelimeler: Kist hidatik, memede kitle, meme kist hidatiği

\section{INTRODUCTION}

Echinococcus granulosus' introduction into the human body as an intermediate host occurs by intake of larvae through infected foods, absorption through the duodenum and venous system, it reaches the liver and clings to the sinusoids, and causes hydatid cysts. Larvae that reach beyond the sinusoids lead to the disease in peripheral organs via systemic circulation (1). Hydatid cyst is seen in the liver by $70 \%$ and in the lungs by $12 \%$. While hydatid cyst of the breast is highly rare, it corresponds to $0.27 \%$ of all cases of the disease $(2,3)$. Diagnosis involves utilization of anamnesis, physical examination, imaging methods and serological tests. The treatment approach in hydatid cyst of the breast is total cystectomy. In this article, we aimed to present our case who was diagnosed with hydatid cyst of the breast and given treatment.

\section{CASE REPORT}

The forty-eight-year-old female patient visited with complaints of a mass she noticed by hand in her right breast. She had a history of surgery about 1 year ago due to hydatid cyst in her lung. The physical examination of the patient found a smooth-surface and mobile mass lesion with a size of approximately 10 $\mathrm{cm}$ in the outer medial quadrant of the patient's right breast. The thoracotomy incision line extended up to the anterior axillary line. Routine laboratory values were in the normal interval. Indirect hemagglutination test (IHA) was found to be positive (1/320). In the breast ultrasonography (USG), a high-pressure cystic mass of an $8 \mathrm{~cm}$ diameter was detected with regular boundaries and anechoic thick walls. An opacity with clear boundaries was observed in the mammography (Figure 1a, 1b). The breast magnetic resonance image (MRI) of the patient revealed a T2A hyperintense T1A hypointense non-contrasted septa-free thick-wall cystic lesion (Figure 2a, 2b). Surgery was planned for the patient with the preliminary diagnosis of hydatid cyst of the breast. The present cyst was excised in total without disturbing tissue integrity (Figure 3). There was no intraoperative complication. The patient was discharged in the 2nd postoperative days without an issue. Pathological examination reported that the mass matched hydatid cyst. The patient aaproval was received.

\section{Received/Geliş Tarihi: 20.10.2018 Accepted/Kabul Tarihi: 27.12.2018}

Address for Correspondence/Yazar Adresi: Mehmet Patmano MD, Şanlıurfa Training and Research Hospital, Clinic of General Surgery, 


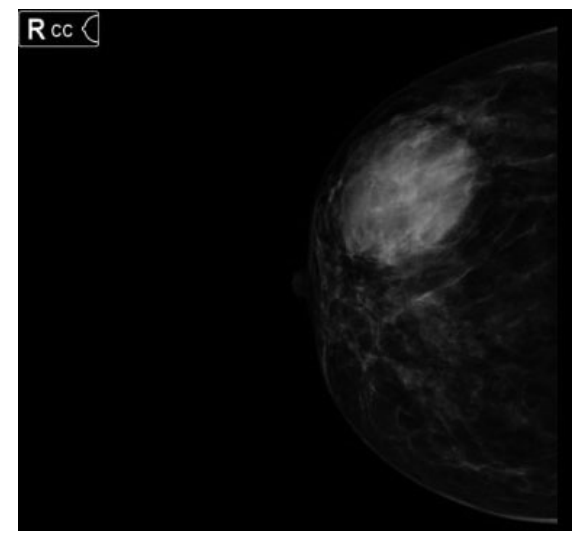

Figure 1a. The mammography craniocaudal image of the cystic mass in the right breast

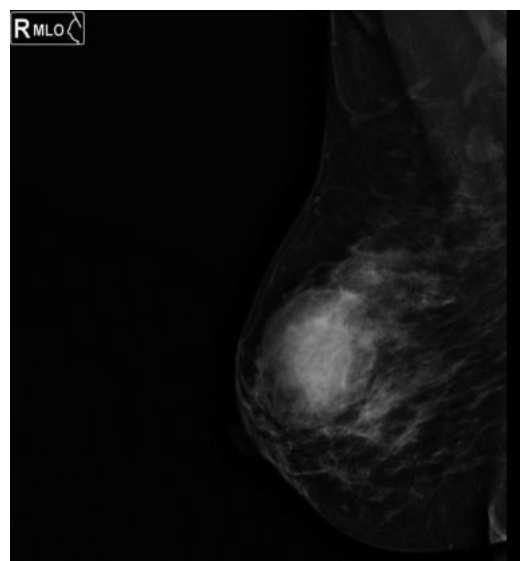

Figure $\mathbf{1 b}$. The mammography mediolateral oblique image of the cystic mass in the right breast

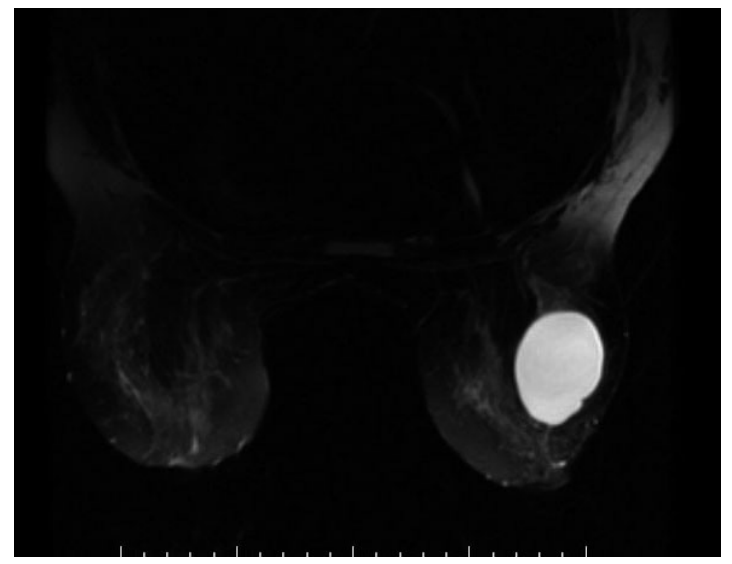

Figure 2a. The magnetic resonance image T1A image of the cystic mass in the right breast

\section{DISCUSSION}

Hydatid cyst is a parasitic disease caused by the parasite echinococcus granulosus whose intermediate hosts are humans. This disease that is endemically seen in Turkey is frequently seen in parts of the world where animal husbandry is prevalent like South America, Australia, New Zealand, Russia and Mediterranean countries. The incidence of human hydatid cysts has been

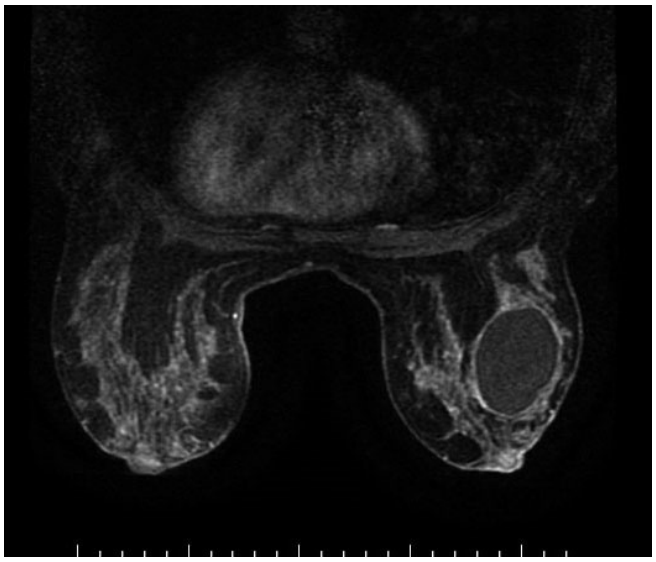

Figure $\mathbf{2 b}$. The magnetic resonance image T2A image of the cystic mass in the right breast,

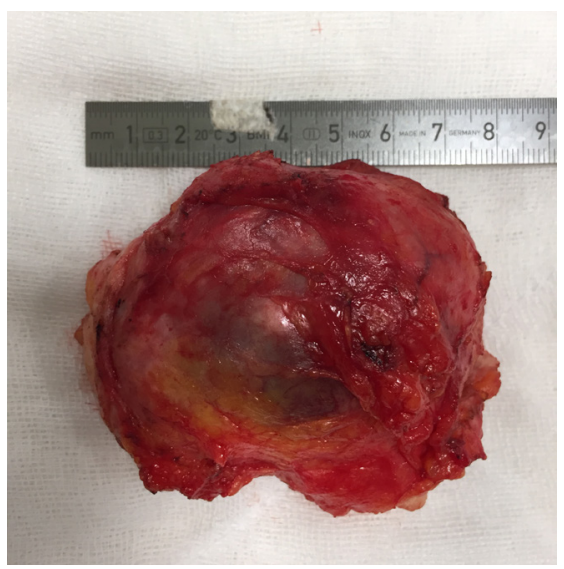

Figure 3. Image of the surgical handpiece

recorded as 18-20 per 100.000 in Turkey $(4,5)$. The organs where the disease settles most frequently are the liver and the lungs. The rarer settlement regions of the disease outside the liver and the lungs in order of frequency may be listed as the spleen, soft tissue, abdomen, kidney, brain, bone, pancreas, breast, pelvis, joints, bladder, heart, ovaries, thyroid, retroperitonea, incision scars and choledochus (6).

The breast is a very rare settlement point for hydatid cysts, and its frequency among all hydatid cysts was reported as $0.27 \%$ (3). Hydatid cyst of the breast is usually detected as a slowly growing mass without pain or by coincidence during routine mammography scans (6-8). Our case had a complaint of an increasingly growing mass that could be felt by hand. It is detected in physical examinations as a hard and mobile mass with regular boundaries. In our patient, it was felt by hand as a palpable mass with a regular surface at the outer medial quadrant of the right breast. Diagnosis involves history, radiological imaging methods and serological tests. The breast USG revealed lesions in the breast with clear boundaries contoured in a lobular way, which could contain cystic and solid regions $(8,9)$. It is seen in mammography as a homogenous, regularly bounded, round and non-specific lesion. In differential diagnosis, other cystic lesions of the breast, fibroadenoma and chronic abscess should also be considered $(7,8)$. Vega et al. (8), using high-dosage mammography, reported the presence of ring-shaped structures in the mass, they 
thought daughter vesicles and different densities in the cyst walls formed in hydatid cysts full of fluids with this appearance, and they defined this situation as a characteristic for hydatid cysts. In breast MRI, this disease appears as a clearly-bounded cystic lesion with capsular contrast retention. In our patient, it was observed as a high-pressure cystic mass of an $8 \mathrm{~cm}$ diameter was detected with regular boundaries and anechoic thick walls in the breast USG, as a clearly-bounded opacity in the mammography, and as a T2A hyperintense T1A hypointense non-contrasted septafree thick-wall cystic lesion in the breast MRI. After imaging, diagnosis may be made by fine-needle aspiration biopsy (FNAB) in case of detection of layered membranes or hooks. Surgical treatment, percutaneous interventions and drug therapy are the treatment of hydatid cyst disease caused by Echinococcus granulosus. Benzimidazoles are the most commonly used agents in the medical treatment of hydatid cyst disease in selected cases and are generally well tolerated. Albendazole is used for a shorter time than mebendazole and is still better responded. FNAB procedure was not carried out on our patient as she had a history of hydatid cyst surgery, a type 5 calcified cyst in her liver based on the Gharbi classification, her hydatid cyst IHA was positive and the imaging procedures supported the diagnosis of hydatid cyst. In the case of hydatid cyst of the breast, the recommended treatment approach is cystectomy $(10,11)$. In our patient, only the cystic lesion was removed by a safe margin, and no additional treatment was provided.

\section{CONCLUSION}

Consequently, while hydatid cyst of the breast is very rare, it should be kept in mind in the case of cystic lesions in the breast in endemic regions such as Turkey. Its treatment is surgical, and the cyst should be excised in total.

\section{* Ethics}

Informed Consent: The patient aaproval was received.

Peer-review: Externally and internally peer-reviewed.

\section{* Authorship Contributions}

Concept: M.P., D.A.Ç., Design: M.P., D.A.Ç., Data Collection or Processing: M.P., T.G., Analysis or Interpretation: M.P., Y.Y., Literature Search: M.P., Y.Y., T.G., Writing: M.P.

Conflict of Interest: No conflict of interest was declared by the authors.

Financial Disclosure: The authors declared that this study has received no financial support.

\section{REFERENCES}

1. Ammann RW, Eckert J. Cestodes Echinococcus. Gastroenterol Clin Nort Am 1996;25:655-89.

2. Ahmadi NA, Badi F. Human hydatidosis in Tehran, Iran: a retrospective epidemiological study of surgical cases between 1999 and 2009 at two university medical centers. Trop Biomed 2011;28:450-6.

3. Pezeshki A, Kia EB, Gholizadeh A, Koohzare A. An analysis of hydatid cyst surgeries in Tehran Milad hospital, Iran, during 2001-2004. Pak J Med Sci 2007;23:138-40.

4. Gündoğdu C, Arslan R, Arslan MÖ, Gıık Y. Erzurum ve çevresinde insanlarda kistik ve alveolar Ekinokokkozis olgularının değerlendirilmesi. Türk Parazitol Derg 2005;29:163-6.

5. Kavukc S, Kilic D, Tokat AO, Kutlay H, Cangir AK, Enon S, et al. Parenchyma-preserving surgery in the management of pulmonary hydatid cysts: analysis of 1032 cases. J Invest Surg 2006;19:60-8.

6. Hakverdi S, Sayar H, Yaldız M, Erdoğan Ş, Akansu B, Canda MŞ, Çukurova yöresinde seyrek yerleşimli ekinokokkozis. Türk Parazitol Derg 2009;33:77-81.

7. İnci E, Aydın S, Baysal N, Çeliker FB, Hatipoğlu E, Bayramoğlu S, ve ark. İzole primer meme hidatik kisti: Olgu sunumu. Bakırköy Tıp Derg 2006;2:31-2.

8. Vega A, Ortega E, Cavada A, Garijo F. Hydatid cyst of the breast: mammographic findings. AJR Am Roentgenol 1994;162:825-6.

9. Yaghan RJ. Hydatid disease of the breast: a case report and literature review. Am J Trop Med Hyg 1999;61:714-5.

10. Ünlü Y, Özardalı İ, Er C. Memede kist hidatik olgu sunumu. Türk Patoloji Derg 1999;15:101-2.

11. Sagin HB, Kiroglu Y, Aksoy F. Hydatid cyst of the breast diagnosed by fine needle aspiration biopsy. A case report. Acta Cytol 1994;38:965-7. 